\title{
Faktor Yang Mempengaruhi Perilaku Pencegahan Luka Kaki Diabetik Pada Pasien Diabetes
}

\author{
Siti Rohmah \\ Fakultas Ilmu Kesehatan Universitas Galuh Ciamis \\ e-mail : rohmah.siti.87@gmail.com \\ (Diterima 04-03-2019; disetujui 25-04-2019; dipublish 09-05-2019)
}

\begin{abstract}
Abstrak
Pasien Diabetes Melitus dengan komplikasi kaki diabetik memiliki dampak yang signifikan terhadap kualitas hidup, misalnya kehilangan mobilitas yang terkait dengan adanya luka pada kaki yang dapat berpengaruh pada kemampuan pasien untuk melakukan tugas sehari hari secara sederhana. Tujuan penelitian ini adalah Mengetahui pengaruh langsung maupun tidak langsung serta besaran antara pengaruh dukungan tenaga kesehatan, pengetahuan, motivasi dan sikap pasien terhadap perilaku pencegahan luka kaki pada pasien diabetes di ruang rawat inap penyakit dalam RSUD Ungaran Semarang.Metode yang digunakan dalam penelitian ini adalah pendekatan kuantitatif yang menggunakandesaincross-sectional (potong lintang). Sampel yang digunakan sebanyak 70 pasien diabetes sebagai responden.Metode analisis yang digunakan adalah Structural Equation Model (SEM) menggunakan SmartPLS 2.0 dan SPSS 20. Hasil pengujian hipotesis dengan Structural Equation Model (SEM) dengan metode smartPLS menghasilkan temuan penelitian yaitu variabel perilaku Pencegahan LKD di RSUD Ungaran Semarang dipengaruhi oleh dukungan nakes $(22.86 \%)$, pengetahuan (20.53\%), motivasi kerja $(22.99 \%)$ dan sikap (13.34\%). Pengaruh langsung Perilaku Pencegahan LKD sebesar 79.7\% dan pengaruh tidak langsung sebesar 1.19\%. Model hasil analisis dapat menjelaskan 98.9\% keragaman data dan mampu mengkaji fenomena yang dipakai dalam penelitian, sedangkan $1.1 \%$ dijelaskan komponen lain yang tidak ada dalam penelitian ini. Saran penelitian hendaknya bagi pihak rumah sakit lebih meningkatkan pemberian informasi yang mendalam kepada pasien dan keluarga tentang pencegahan diabetes sebagai salah satu keberhasilan terapi diabetes mellitus misalnya dengan pemberian leaflet tentang diabetes mellitus dan komplikasinya.
\end{abstract}

Kata Kunci:Dukungan Tenaga Kesehatan, Pengetahuan, Motivasi, Sikap Perilaku

\begin{abstract}
Diabetes Mellitus Patients with diabetic foot complications have a significant impact on quality of life, such as loss of mobility associated with sores on the feet that can affect the patient's ability to perform simple everyday tasks. The purpose of this study was to know the effect, directly or indirectly, and the magnitude of the effect of the support of health professionals, knowledge, motivation and attitudes of patients toward prevention behavior foot wounds in diabetic patients in the inpatient unit disease in hospitals Ungaran Semarang. The method used in the study this is a quantitative approach that uses cross-sectional design (cross-sectional). The samples used were 70 patients with diabetes as respondents. The analytical method used is Structural Equation Model (SEM) using SmartPLS 2.0 and SPSS 20. Results of testing the hypothesis by Structural Equation Model (SEM) method smartPLS produce research findings that behavioral variables Prevention LKD in hospitals Ungaran Semarang influenced by the support of health workers (22.86\%), knowledge (20:53\%), motivation (22.99\%) and attitude (13:34\%). The direct effect LKD Behavior Prevention of 79.7\% and the indirect influence of 1:19\%. Model analysis results can explain the diversity of data and $98.9 \%$ were able to examine the phenomenon used in the study, while $1.1 \%$ described other components that do not exist in this study. Suggestions studies for hospitals should further improve the provision of in-depth information to patients and families about diabetes prevention as one of the therapeutic efficacy of diabetes mellitus for example by giving leaflets about diabetes mellitus and its complications.
\end{abstract}

Keywords:Health Workers Support, Knowledge, Motivation, Attitude Behavior 


\section{Pendahuluan}

Diabetes mellitus adalah gangguan kronis yang mempengaruhi kemampuan tubuh untuk menghasilkan atau menggunakan insulin. Diabetes mellitus (DM) merupakan suatu penyakit sebagai akibat dari kelainan metabolisme yang disebabkan karena ketidakmampuan pankreas menghasilkan insulin, sehingga waktu kerja insulin menjadi terhambat dan mengakibatkan kadar gula darah meningkat. ${ }^{1}$

Peningkatan angka kejadian diabetes mellitus sendiri berhubungan dengan meningkatnya faktor resiko diantaranya obesitas atau kegemukan, kurangnya aktivitas fisik, kurang mengkonsumsi makanan berserat tinggi, tinggi lemak, merokok dan kelebihan kolesterol. Diabetes atau kencing manis ditandai dengan tingginya kadar gula dalam darah. Penyakit ini juga sering disebut dengan the great imitator karena dapat menyerang semua organ tubuh dan menimbulkan keluhan.

World Health Organization (WHO) memperkirakan jumlah penduduk dunia yang menderita diabetes mellitus pada tahun 2030 diperkirakan akan meningkat paling sedikit menjadi 366 juta. Setiap tahun penderita diabetes di Indonesia semakin meningkat. Saat ini, Indonesia menempati urutan ke-4 terbesar dalam jumlah penderita diabetes mellitus dengan prevalensi 8,6\% dari total penduduk setelah India, Cina, dan Amerika Serikat. Diabetes Melitus merupakan penyebab kematian nomor 6 di Indonesia. Hal ini menunjukkan bahwa di Indonesia, penyakit diabetes mellitus merupakan masalah kesehatan masyarakat yang sangat serius. Faktor lingkungan dan gaya hidup yang tidak sehat, seperti makan berlebihan, berlemak, kurang aktivitas dan stres berperan sangat besar sebagai pemicu Diabetes Mellitus. Selain itu Diabetes Mellitus juga bisa muncul karena adanya faktor keturunan. ${ }^{2}$

Peningkatan jumlah penderita diabetes dipengaruhi oleh umur, obesitas, kurangnya pengetahuan, kebiasaan hidup yang kurang sehat. Salah satu komplikasi yang paling sering terjadi adalah luka kaki diabetik (IKD). Sekitar $15 \%$ penderita diabetes melitus akan mengalami komplikasi IKD. Infeksi Kaki
Diabetik dapat dicegah agar tidak berubah menjadi gangrene. Salah satu upaya pencegahan terjadi-nya luka kaki diabetic diperlukan perilaku perawatan kaki (foot care behavior) yang sangat baik pada pasien diabetes mellitus. Perawatan kaki meliputi pemeriksaan kaki rutin, identifikasi risiko dari kaki diabetic dan pemberian edukasi serta penatalaksanaan dini.

Jumlah penderita Diabetes Melitus di Indonesia Tahun 2013 terdaftar 56 juta orang. Jumlah penderita Diabetes Mellitus terbanyak terdapat di lima provinsi diantara propinsi lainnya yaitu Jawa Timur 1.2 juta orang, Jawa Barat 1.01 juta orang, Jawa Tengah 922 ribu orang, DKI Jakarta 822 ribu orang, banten 513 ribu orang.Pasien yang memiliki pengetahuan tentang diabetes dan komplikasinya akan berhasil melawan diabetes. Banyak dari masyarakat mengetahui terkena diabetes dan komplikasinya. Salah satu komplikasi yang paling sering terjadi adalah luka Infeksi Kaki Diabetik (IKD). Sekitar $15 \%$ penderita diabetes melitus akan mengalami komplikasi IKD. Infeksi Kaki Diabetik dapat dicegah agar tidak berubah menjadi gangren. ${ }^{3}$

Luka pada kaki diabetes merupakan salah satu komplikasi kronik DM yang paling buruk hasil pengelolaannya. Kaki diabetes yang tidak dirawat dengan baik akan mudah mengalami luka, dan cepat berkembang menjadi ulkus gangren bila tidak dirawat dengan benar. ${ }^{4}$ Pengetahuan tentang diabetes membentuk dasar untuk keputusan tentang diet, olahraga, kontrol berat badan, pemantauan glukosa darah, penggunaan obat, perawatan mata dan kaki, dan kontrol makrovaskuler sebagai faktor risiko. ${ }^{4}$

Departemen Kesehatan Republik Indonesia telah menempuh langkah-langkah pencegahan penyakit Diabetes Mellitus melalui peningkatan penemuan kasus baru, pemberian terapi diet dan pemantauan diit secara rutin, pendidikan dan pelatihan bagi tenaga kesehatan,memberikan diit secara gratis, melakukan upaya intensif terhadap pencegahan penyakit Diabetes Mellitus akut, serta peningkatan penyuluhan perawatan diri bagi penderita Diabetes, namun secara implisit masih belum menunjukkan hasil yang memuaskan. $^{5}$ 
Pengetahuan gizi merupakan faktor yang sangat penting dalam menentukan sikap dan perilaku seseorang terhadap makanan. Selain itu pengetahuan gizi merupakan peranan penting untuk dapat membuat manusia hidup sehat sejahtera dan berkualitas.Pasien Diabetes Melitus dengan komplikasi kaki diabetik memiliki dampak yang signifikan terhadap kualitas hidup, misalnya kehilangan mobilitas yang terkait dengan adanya luka pada kaki yang dapat berpengaruh pada kemampuan pasien untuk melakukan tugas sehari-hari secara sederhana. Beberapa penelitian menunjukkan bahwa pasien Diabetes dengan kaki diabetik akan lebih depresi dan memiliki kualitas hidup yang lebih buruk daripada mereka yang tidak disertai dengan komplikasi. Depresi dianggap sebagai salah satu dari penyebab utama kecacatan, karena akan membatasi fisik mereka dari semua kegiatan baik sosial ataupun pribadi. Cedera kaki pada pasien kaki diabetik dapat mempengaruhi secara signifikan kehidupan sehari-hari dan mungkin memiliki konsekuensi yang berat seperti gangguan psikososial, termasuk depresi. ${ }^{6}$

Untuk mengontrol komplikasi ulkus kaki, tergantung motivasi serta pengetahuan pasien DM mengenali penyakit serta komplikasinya dapat berkontribusi untuk mencegah kaki diabetik. Jika pasien memiliki pengetahuan yang memadai mereka akan dapat berlatih untuk mencegah ulkus diabetik.Pengetahuan seseorang erat kaitannya dengan perilaku yang akan diambilnya, karena dengan pengetahuan tersebut pasien memiliki alasan dan landasan untuk menentukan suatu pilihan. Dengan pengetahuan manusia dapat mengembangkan apa yang diketahuinya dan dapat mengatasi kebutuhan kelangsungan hidup, sehingga akan mempengaruhi seseorang dalam berperilaku. Terbentuknya perilaku baru terutama pada orang dewasa dimulai pada domain kognitif dalam arti subyek tahu terlebih dahulu terhadap stimulus yang berupa materi atau obyek diluarnya, sehingga menimbulkan pengetahuan baru dan akan terbentuk dalam sikap maupun tindakan. ${ }^{7}$

Bila seorang pasien mempunyai pengetahuan tentang risiko terjadinya ulkus diabetes, maka pasien akan dapat memilih alternatif yang terbaik bagi dirinya dan cenderung memperhatikan hal-hal yang penting tentang perawatan diabetes melitus seperti pasien akan melakukan pengaturan pola makan yang benar, berolah raga secara teratur, mengontrol kadar gula darah dan memelihara lingkungan agar terhindar dari benda-benda lain yang dapat menyebabkan luka. Apabila perawatan yang dilakukan dengan tepat maka dapat membantu proses penyembuhan dan diharapkan pasien menjadi sehat baik fisik, mental, sosial dan spiritual.Perawatan kesehatan diri terdiri dari empat aspek yakni memantau glukosa darah, diet, pengobatan dan latihan. Hal ini diketahui bahwa faktor-faktor yang beragam mempengaruhi perawatan kesehatan diri terhadap suatu penyakit seperti pengetahuan dan aspek emosional.

Diperlukan motivasi yang kuat sehingga dorongan dari dalam diri seseorang yang menyebabkan seseorang tersebut melakukan kegiatan-kegiatan tertentu guna mencapai suatu tujuan. motivasi yang berasal dari dalam diri manusia, biasanya timbul dari perilaku yang dapat memenuhi kebutuhan sehingga menjadi puas yang dapat diamati adalah kegiatan atau mungkin alasan-alasan tindakan tersebut.Motivasi dikatakan kuat apabila dalam diri seseorang dalam kegiatankegiatan sehari-hari memiliki harapan yang positif, mempunyai harapan yang tinggi, dan memiliki keyakinan yang tinggi bahwa penderita akan menyelesaikan pengobatannya tepat pada waktu yang telah ditentukan. ${ }^{8}$

Kaki diabetik adalah infeksi atau kerusakan pada jaringan yang berhubungan dengan gangguan saraf dan gangguan aliran darah pada tungkai kaki. Penyakit Diabetes mellitus merupakan 10 penyakit terbanyak yang ada di RSUD Ungaran Semarang. Data tersebut menunjukkan angka kejadian Diabetes Mellitus begitu tinggi bila dibandingkan dengan angka kejadian penyakit lainnya.Sedangkan angka kejadian Diabetes Mellitus akut dapat berkembang menjadi komplikasi penyakit lain, jika tidak dilakukan diit dengan segera.Pada tingkatan ini banyak Diabetes Mellitus masih lokal secara klinis dan potensial diobati dengan terapi diet.Berdasarkan temuan observasi pendahuluan tersebut, maka rumusan masalah 
dalam penelitian ini adalah belum diketahuinya pengaruh langsung dan tidak langsung serta besarannya antara dukungan tenaga kesehatan, pengetahuan, motivasi dan sikap pasien terhadap perilaku pencegahan luka kaki pada pasien diabetes di ruang rawat inap penyakit dalam RSUD Ungaran Semarang .

Adapun Tujuan diadakannya penelitian ini adalah untuk mengetahui pengaruh langsung maupun tidak langsung serta besaran antara pengaruh dukungan tenaga kesehatan, pengetahuan, motivasi dan sikap pasien terhadap perilaku pencegahan luka kaki pada pasien diabetes di ruang rawat inap penyakit dalam RSUD Ungaran Semarang.

\section{Metode}

Penelitian ini adalah penelitian Survey dengan desain Cross Sectional Yang bertujuan untuk menganalisis hubungan kausal antara variabel-variabel melalui pengujian hipotesis yaitu untuk menganalisis pengaruh langsung dan tidak langsung serta besarannya antara pengetahuan, dukungan tenaga kesehatan, motivasi dan sikap terhadap perilaku pencegahan luka kaki diabetik pada pasien diabetes di ruang rawat inap penyakit dalam RSUD Ungaran Semarang.

Populasi adalah kelompok atau kumpulan individu-individu atau objek penelitian yang memiliki standar tertentu dari ciri-ciri yang telah ditetapkan sebelumnya.Populasi dalam penelitian ini adalah semua lansia penderita penyakit Diabetes Mellitus di RSUD Ungaran semarang.Sampel adalah sebagian dari populasi yang sifatnya representative (mampu mewakili populasi).Cara pengambilan sampel menggunakan purposive sampel dengan kriteria inklusi dan eksklusi. Sampel yang diambil dalam penelitian, 60 orang penderita penyakit Diabetes Mellitus. Kriteria inklusi dan eksklusi sampel dalam penelitian ini adalah: (1).Kriteria Inklusi Responden (Responden dengan penyakit Diabetes Mellitus; dan Responden pernah melakukan pemeriksaan dini terkait penyakit Diabetes Mellitus dalam 6 bulan terakhir sejak tanggal pertama tercatat sebagai pasien di RSUD Ungaran semarang); (2).Kriteria Eksklusi, adalah kriteria inklusi yang karena keadaan tertentu dikeluarkan dari kriteria
inklusi.Keadaan tersebut adalah responden tiba-tiba berhalangan hadir. Responden yang berhalangan hadir dan tidak bersedia digantikan oleh responden lain yang memenuhi kriteria inklusi.

Dalam penelitian ini analisis data menggunakan pendekatan Partial Least Square (PLS). PLS adalah model persamaan Structural Equation Modeling (SEM) yang berbasis komponen atau varian.PLS merupakan pendekatan alternatif yang bergeser dari pendekatan SEM berbasis kovarian menjadi berbasis varian. ${ }^{9}$

SEM yang berbasis kovarian umumnya menguji kausalitas/teori sedangkan PLS lebih bersifat predictive model.PLS merupakan metode analisis yang powerfull, karena tidak didasarkan pada banyak asumsi.Misalnya, data harus berdistribusi normal, sampel tidak harus besar. Selain dapat digunakan untuk mengkonfirmasi teori, PLS juga dapat digunakan untuk menjelaskan ada tidaknya hubungan antar variabel laten. PLS dapat sekaligus menganalisis konstruk yang dibentuk dengan indikator reflektif dan formatif.

Estimasi parameter yang didapat dengan PLS dapat dikategorikan menjadi tiga. Pertama, adalah weight estimate yang digunakan untuk menciptakan skor variabel laten. Kedua, mencerminkan estimasi jalur (path estimate) yang menghubungkan variabel laten dan antar variabel laten dan indikatornya (loading). Ketiga, berkaitan dengan means dan lokasi parameter (nilai konstanta regresi) untuk indikator dan variabel laten. Untuk memperoleh ketiga estimasi ini, PLS menggunakan proses iterasi 3 tahap dan setiap tahap iterasi menghasilkan estimasi. Tahap pertama, menghasilkan weight estimate, tahap kedua menghasilkan estimasi untuk inner model dan outer model, dan tahap ketiga menghasilkan estimasi means dan lokasi. ${ }^{10}$

Diagram jalur SEM berfungsi untuk menunjukkan pola hubungan antar variabel yang kita teliti. Dalam SEM pola hubungan antar variabel akan diisi dengan variabel yang diobservasi, variabel laten dan indikator. Didasarkan pola hubungan antar variabel, SEM dapat diurai menjadi dua sub-bagian yaitu: model pengukuran dan model structural.Sedangkan model struktural 
mendefinisikan hubungan antar semua variabel yang tidak diobservasi. Itulah sebabnya model struktural mengidentifikasi variabel-variabel laten mana saja yang secara langsung ataupun tidak langsung mempengaruhi perubahan nilai variabel laten lainnya dalam model.Beberapa fungsi SEM, diantaranya ialah:(a).Memungkinkan adanya asumsi-asumsi yang lebih fleksibel; (b).Penggunaan analisis faktor penegasan (confirmatory factor analysis) untuk mengurangi kesalahan pengukuran dengan memiliki banyak indikator dalam satu variabel laten; (c).Daya tarik interface pemodelan grafis untuk memudahkan pengguna membaca keluaran hasil analisis; (d).Kemungkinan adanya pengujian model secara keseluruhan dari pada koefesien-koefesien secara sendirisendiri. (e).Kemampuan untuk menguji modelmodel dengan menggunakan beberapa variabel tergantung; (f).Kemampuan untuk membuat model terhadap variabel-variabel perantara; dan (g).Kemampuan untuk membuat model gangguan kesalahan (error term).

\section{Hasil}

Data penelitian dikumpulkan dari 70 pasien diabetes di RSUD Ungaran Semarang. Karakteristik Responden dalam penelitian ini meliputi usia, pendidikan dan pekerjaan.

Sebagian besar responden berusia 30-35 tahun sebanyak 38 responden (48\%), sedangkan responden dengan usia 20-30 tahun sebanyak 22 responden (28\%) dan usia lebih dari 35 tahun sebanyak 10 responden (13\%).Berdasarkan kelompok pendidikan sebagian besar responden berpendidikan SLTA sebanyak 51 responden (64\%), sedangkan responden berpendidikan akademi ada sebanyak 24 responden (27\%) dan responden berpendidikan sarjana sebanyak 8 responden (9\%).Berdasarkan pekerjaan sebagian besar responden bekerja sebanyak 63 responden $(81 \%)$, sedangkan responden yang tidak bekerja ada sebanyak 17 responden (19\%).

Data responden dinyatakan dalam beberapa kategori disertai dengan perhitungan nilai range (kisaran), mean (rata-rata) dan standar deviasi (penyimpangan). Statistik deskriptif variabel penelitian digunakan untuk memberikan gambaran tentang tanggapan responden mengenai variabel-variabel penelitian yang menunjukkan angka minimum, maksimum, rata-rata serta standar deviasi.

Data responden juga dapat dinyatakan dalam beberapa kategori disertai dengan perhitungan nilai range (kisaran), mean (ratarata) dan standar deviasi (penyimpangan).pada variabel Perilaku Pencegahan LKD, penilaian terhadap Perilaku Pencegahan LKD pada Pasien antara 27-75 mendekati kisaran teoritisnya (15-75) dengan nilai rata-rata 50 dan standar deviasi 9.306.

Hal ini mengindikasikan bahwa responden cenderung menganggap penting Perilaku Pencegahan LKD di RSUD Ungaran Semarang.Pada variabel Dukungan nakes kisaran jawaban responden antara 26-74 mendekati kisaran teoritisnya pada nilai tertinggi (25-125) dengan nilai rata-rata 50.22 dan standar deviasi 10.376. Hal ini mengindikasikan persepsi responden cenderung menganggap penting Dukungan nakes.

Pada variabel Pengetahuan kisaran jawaban responden antara 27-75 mendekati kisaran teoritisnya pada nilai tertinggi (15-75) dengan nilai rata-rata 50.32 dan standar deviasi 10.464. Hal ini mengindikasikan persepsi responden cenderung menganggap penting variabel Pengetahuan. Pada variabel Motivasi, penilaian terhadap Motivasi antara 42-75 mendekati kisaran teoritisnya (15-75) dengan nilai rata-rata 56.9 dan standar deviasi 6.936. Hal ini mengindikasikan bahwa responden cenderung menganggap penting Motivasi.Pada variabel Sikap, penilaian terhadap Sikap antara 40-74 mendekati kisaran teoritis-nya (15-75) dengan nilai rata-rata 52.22 dan standar deviasi 6834. Hal ini mengindikasikan bahwa responden cenderung menganggap penting Sikap.

Pada Variabel Perilaku Pencegahan LKD nilai jawaban responden terkecil adalah 27 dan yang terbesar adalah 75 dengan ratarata 50.00 median 51 dan nilai jawaban yang terbanyak adalah 51.Untuk variabel Dukungan nakes nilai jawaban responden terkecil adalah 26 dan yang terbesar adalah 74 dengan ratarata 50.22 median 51 dan nilai jawaban yang terbanyak adalah 50.Untuk variabel Pengetahuan nilai jawaban responden terkecil adalah 27 dan yang terbesar adalah 75 dengan 
rata-rata 50.325 median 50 dan nilai jawaban yang terbanyak adalah 50.Untuk variabel Motivasi nilai jawaban responden terkecil adalah 40 dan yang terbesar adalah 74 dengan rata-rata 56.90 median 56 dan nilai jawaban yang terbanyak adalah 56. Untuk variabel Sikap nilai jawaban responden terkecil adalah 42 dan yang terbesar adalah 75 dengan ratarata 52.22 median 52 dan nilai jawaban yang terbanyak adalah 52 .

Uji Chi Square Test dilakukan untuk melihat variasi total jawaban responden per variabel terhadap karakteristik penelitian. Hasil dari uji Chi Square Test variabel Perilaku Pencegahan LKD tersebut dapat dilihat bahwa variabel Perilaku Pencegahan LKD tidak dipengaruhi oleh karakteristik responden karena hasil uji Chi Square dengan taraf signifikansi 5\% semuanya lebih besar dari 0,05 .

Hasil dari uji Chi Square Test variabel Dukungan nakes dapat dilihat bahwa variabel Dukungan nakes tidak dipengaruhi oleh karakteristik responden karena hasil uji Chi Square dengan taraf signifikansi 5\% semuanya lebih besar dari 0,05 . Ini menunjukkan variabel Dukungan nakes tidak ada hubungan dengan karakteristik responden.
Variabel motivasi tidak dipengaruhi oleh karakteristik responden karena hasil uji Chi Square dengan taraf signifikansi 5\% semuanya lebih besar dari 0,05. Ini menunjukkan variabel Motivasi tidak ada hubungan dengan karakteristik responden.Variabel sikap tidak dipengaruhi oleh karakteristik responden karena hasil uji Chi Square dengan taraf signifikansi 5\% semuanya lebih besar dari 0,05 . Ini menunjukkan variabel Sikap tidak ada hubungan dengan karakteristik responden.

Structural Equation Modelling (SEM) merupakan salah satu analisis multivariate yang dapat menganalisis hubungan variabel secara kompleks.Analisis ini pada umumnya digunakan untuk penelitian-penelitian yang menggunakan banyak variabel.Teknik analisis data menggunakan Structural Equation Modelling (SEM) dilakukan untuk menjelaskan secara menyeluruh hubungan antar variabel yang ada dalam penelitian.Structural Equation Modelling (SEM) digunakan bukan untuk merancang suatu teori, tapi lebih ditujukan untuk memeriksa dan membenarkan suatu model.

Syarat utama menggunakan model

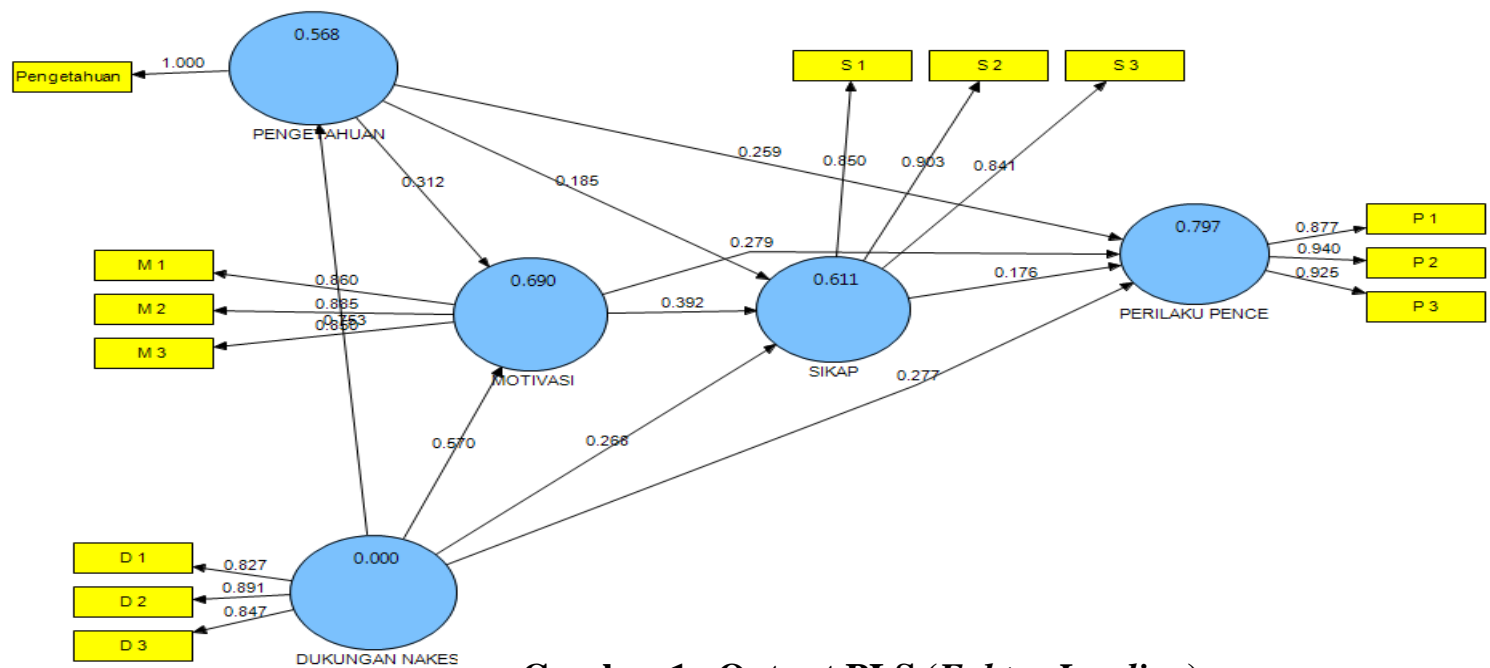

Gambar 1. Output PLS (Faktor Loading)

Hasil dari uji Chi Square Test variabel Pengetahuan tersebut dapat dilihat bahwa variabel Pengetahuan tidak dipengaruhi oleh karakteristik responden karena hasil uji Chi Square dengan taraf signifikansi 5\% semuanya lebih besar dari 0,05. Ini menunjukkan variabel Pengetahuan tidak ada hubungan dengan karakteristik responden.
Structural Equation Modelling (SEM) adalah membangun suatu model hipotesis yang terdiri dari model struktural dan model pengukuran dalam bentuk diagram jalur berdasarkan justifikasi teori. Structural Equation Modelling (SEM) merupakan kumpulan teknik-teknik statistic yang memungkinkan pengujian sebuah rangkaian 
hubungan secara simultan. Hubungan itu dibangun antara satu atau beberapa variabel eksogen.

Dari gambar 1 terlihat bahwa nilai faktor loading telah memenuhi persyaratan yaitu nilai loading factors lebih besar dari 0,5. Suatu indikator reflektif dinyatakan valid jika mempunyai loading factor diatas 0,5 terhadap konstruk yang dituju berdasarkan pada substantive content-nya dengan melihat signifikansi dari weight $(\mathrm{t}=1,96)$.

Hasil evaluasi outer model terdiri dari nilai outer loading, cross loading, faktor loading, convergent validity, AVE, serta nilai composite reliability.Untuk Mengetahui apakah variabel mampu memprediksi lebih tinggi faktor loading indikatornya dibandingkan prediksi terhadap indikator lainnya dengan melihat nilai cross loading.nilai faktor loading D1 - D3 lebih tinggi untuk konstruk dukungan Nakes dibanding konstruk lainnya, sehingga konstruk dukungan Nakes mampu memprediksi nilai faktor loading harag hingga rasa aman lebih tinggi daripada konstruk lainnya. Demikian pula untuk faktor loading untuk konstruk variabel sikap, Perilaku Pencegahan LKD, Dukungan nakes dan Motivasi dibanding konstruk lainnya masih lebih tinggi nilai faktor loadingnya dibandingkan dengan konstruk yang lainnya.

Hasil analisis pengolahan data terlihat bahwa konstruk yang digunakan untuk membentuk sebuah model penelitian, pada proses analisis faktor konfirmatori telah memenuhi kriteria goodness of fit yang telah ditetapkan. Nilai probability pada analisis ini menunjukkan nilai di atas batas signifikansi yaitu 0,05 .

Dari hasil pengolahan data juga terlihat bahwa setiap indikator atau dimensi pembentuk variabel laten menunjukkan hasil yang baik, yaitu.Dengan hasil ini, maka dapat dikatakan bahwa indikator pembentuk variabel laten konstruk Sikap, Motivasi, Dukungan nakes, dengan nilai loading factor yang tinggi di mana masing-masing indikator lebih besar dari 0,5. Motivasi dan Perilaku Pencegahan LKD tersebut sudah menunjukkan hasil yang baik.

Cara menguji discriminant validity yaitu melalui Square root of average variance extracted ( $A V E$ ), dengan cara membandingkan nilai akar AVE dengan korelasi antar konstruk. Berikut dibawah ini tabel AVE dan hasil akarnya.

Tabe1 1 . Evaluasi Average Variance Extracted

\begin{tabular}{cccc}
\hline Variabel & AVE & $\begin{array}{c}\text { Akar } \\
\text { AVE }\end{array}$ & $\begin{array}{c}\text { Kriteria } \\
\text { Uji }>\mathbf{0 , 5}\end{array}$ \\
\hline Dukungan Nakes & $\begin{array}{c}0.73169 \\
5\end{array}$ & 0.855392 & Valid \\
\hline Motivasi & 0.74830 & 0.865047 & Valid \\
Pengetahuan & 1 & 1 & Valid \\
Perilaku & 0.83678 & 0.914758 & Valid \\
Pencegahan LKD & 2 & & \\
Sikap & 0.74859 & 0.865212 & Valid \\
\hline Sumber: output SmartPLS 2.0, 2016 &
\end{tabular}

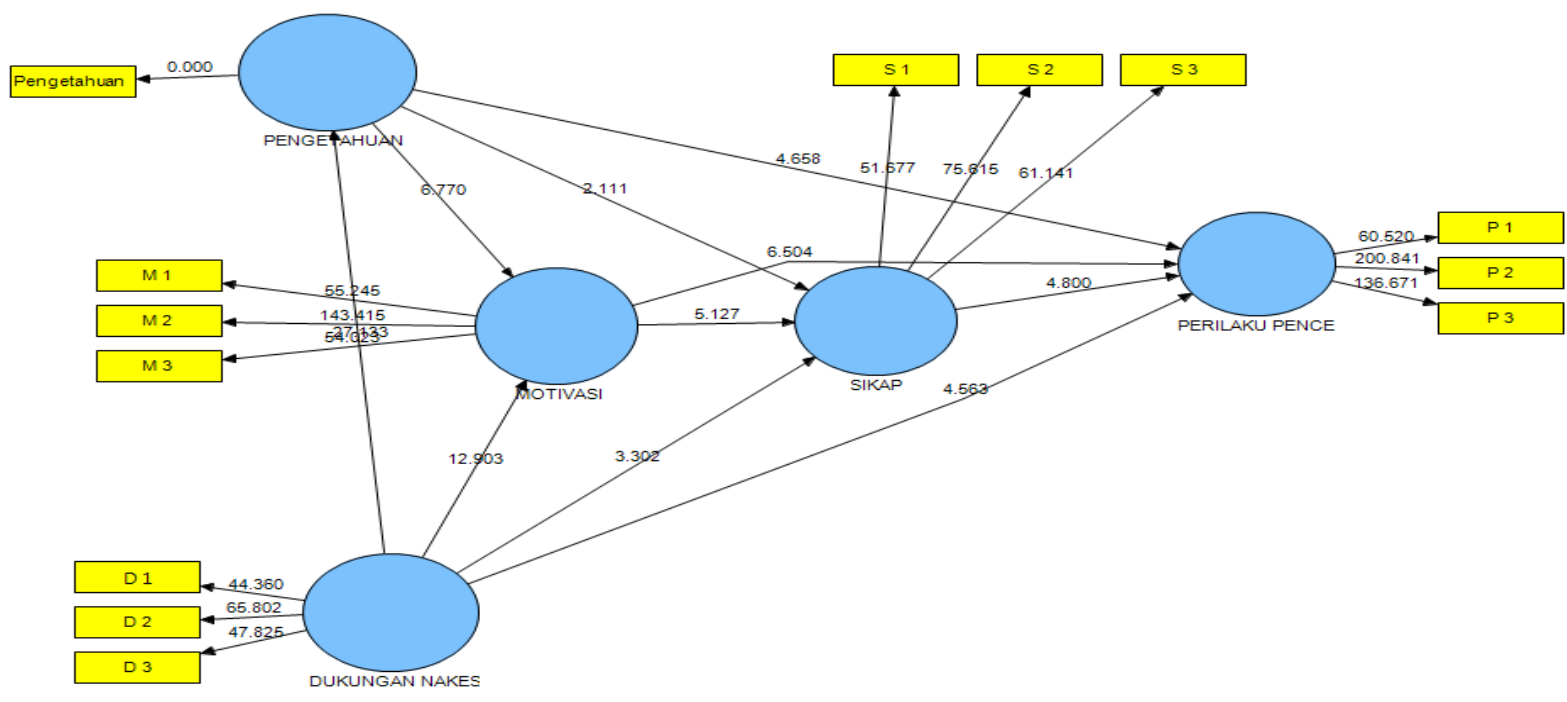


Berdasarkan tabel 1 dapat dilihat semua variabel dinyatakan valid karena memberikan nilai AVE diatas 0,5. Sehingga dapat disimpulkan bahwa evaluasi pengukuran model memiliki diskriminan validity yang baik atau valid. Metode lain untuk menilai diskriminan validity adalah membandingkan nilai Square root of average variance extracted (AVE) setiap konstruk dengan korelasi antara konstruk dengan konstruk lainnya dalam model maka dikatakan memiliki nilai diskriminan validity yang baik.

Setelah diuji validitas dan dinyatakan variabel dan indikator telah valid maka dilakukan uji reliabilitas. uji reliabilitas dilakukan dengan melihat nilai composite reliability dari blok indikator yang mengukur konstruk hasil composite reliability akan menunjukkan nilai yang memuaskan jika diatas 0.70. hasil evaluasi reliabilitas outer

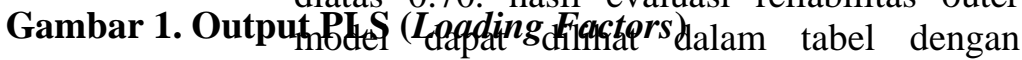
mengevaluasi nilai Cronbach's Alpha dan composite reliability.

Nilai Cronbach's Alpha dan Composite reliability semua variabel memiliki nilai lebih besar dari 0,70 sehingga dapat dikatakan bahwa kontrak memiliki reliabilitas yang baik. Berdasarkan output smartPLS nilai $L V$ Correlation Pengetahuan terhadap perilaku adalah 0.793434, Dukungan nakes terhadap perilaku adalah 0.823866 dan Motivasi terhadap perilaku adalah 0.779375.Hasil evaluasi signifikansi outer model diatur dalam output PLS dibawah ini dengan mengevaluasi refleksi nilai $\mathrm{T}$-Statistic indikator terhadap variabelnya.
Evaluasi signifikansi outer model dilakukan untuk menilai signifikansi konstruk laten dengan konstruksinya yaitu dengan membandingkan nilai $\mathrm{t}$ statistic masing-masing konstruk laten dengan nilai $\alpha=0,05(1,96)$. Untuk mengukur nilai $\mathrm{t}$ statistic dilakukan bootstrapping.

Berdasarkan gambar 2, setelah dilakukan bootstrapping untuk mengukur nilai t statistic dari masing-masing konstruk laten terhadap konstruknya, maka nilai t statistic dibandingkan dengan nilai $\alpha=0,05(1,96)$. Ketentuannya, apabila nilai $t$ statistic lebih besar dari nilai $\alpha=0,05(1,96)$, maka konstruk laten tersebut signifikan terhadap konstruk-nya. Inner model disebut juga dengan nilai $R$ Square, uji hipotesis $T$ statistic, pengaruh variabel langsung dan prediktif (nilai $Q$ Square).

Nilai Q-Square predictive relevance berfungsi untuk menilai besaran keragaman atau variasi data penelitian terhadap fenomena yang sedang dikaji dan hasilnya sebagai berikut.

Tabel 2. Evaluasi Nilai R Square Menurut Variabel Penelitian

\begin{tabular}{lc}
\hline \multicolumn{2}{c}{ Hasil Uji } \\
\hline \multicolumn{1}{c}{ Variabel } & R Square \\
\hline Dukungan Nakes & \\
Motivasi & 0.690259 \\
Pengetahuan & 0.567620 \\
Perilaku Pencegahan & 0.797209 \\
LKD & Sumber: SmartPLS 2.0 report, 2016
\end{tabular}

Tabel 3.Persentase Pengaruh Antar Variabel Terhadap Perilaku Pencegahan LKD 
Tabel 3.Persentase Pengaruh Antar Variabel Terhadap Perilaku Pencegahan LKD

\begin{tabular}{|c|c|c|c|c|c|c|c|}
\hline Sumber & $\begin{array}{c}L V \\
\text { Correlatio } \\
n\end{array}$ & $\begin{array}{c}\text { Direct } \\
\text { Rho }\end{array}$ & $\begin{array}{c}\text { Indirect } \\
\text { Rho }\end{array}$ & Total & $\begin{array}{c}\text { Direct } \\
\%\end{array}$ & $\begin{array}{c}\text { Indirec } \\
t \\
\%\end{array}$ & \%Total \\
\hline $\begin{array}{c}\text { Dukungan } \\
\text { Nakes }\end{array}$ & 0.823866 & $\begin{array}{c}0.27748 \\
6\end{array}$ & 0.541505 & $\begin{array}{c}0.819 \\
0\end{array}$ & $\begin{array}{c}22.86 \\
\%\end{array}$ & $0.94 \%$ & $\begin{array}{c}23.81 \\
\%\end{array}$ \\
\hline Pengetahuan & 0.793434 & $\begin{array}{c}0.25869 \\
8\end{array}$ & 0.1345 & $\begin{array}{c}0.393 \\
2\end{array}$ & $\begin{array}{c}20.53 \\
\%\end{array}$ & $0.24 \%$ & $\begin{array}{c}20.77 \\
\%\end{array}$ \\
\hline Motivasi Kerja & 0.824843 & $\begin{array}{c}0.27876 \\
8\end{array}$ & 0.0689 & $\begin{array}{c}0.347 \\
6\end{array}$ & $\begin{array}{c}22.99 \\
\%\end{array}$ & $0.001 \%$ & $\begin{array}{c}23.00 \\
\%\end{array}$ \\
\hline Sikap & 0.759139 & $\begin{array}{c}0.17572 \\
2 \\
\end{array}$ & - & $\begin{array}{c}0.175 \\
7\end{array}$ & $\begin{array}{c}13.34 \\
\%\end{array}$ & $0.00 \%$ & $\begin{array}{c}13.34 \\
\%\end{array}$ \\
\hline Total & & & & & $79.7 \%$ & $1.19 \%$ & $80.9 \%$ \\
\hline
\end{tabular}

Sumber: Diolah dari SmartPLS 2.0 report, 2016

Hasil uji hipotesis terhadap indikator dari variabel yang diteliti adalah nilai $\mathrm{T}$ statistic direfleksikan terhadap variabelnya sebagian besar $>1,96$, sehingga menunjukkan blok indikator berpengaruh positif dan signifikan untuk merefleksikan variabelnya.Motivasi berpengaruh positif terhadap Perilaku Pencegahan LKD. Hasil uji terhadap koefisien parameter antara dukungan nakes terhadap Perilaku Pencegahan LKD ada pengaruh positif 0.277486 dan nilai T-Statistik sebesar 4.562581, berada jauh diatas nilai kritis $(1,96$. Nilai T-Statistic tersebut berada jauh diatas nilai kritis $(1,96)$.

Hal yang sama juga terjadi pada pengetahuan terhadap Perilaku Pencegahan LKD ada pengaruh positif 0.258698 dan nilai T Statistic sebesar 4.657565 Nilai T-Statistic tersebut berada jauh diatas nilai kritis $(1,96)$. Begitu juga variabel lainnya yang saling mempengaruhi memiliki nilai diatas nilai kritis $(1,96)$. Selanjutnya berdasarkan pola hubungan antar variabel yang digambarkan dalam kerangka konsep, ada hubungan yang bersifat langsung dan tidak langsung.

Dukungan nakes pengaruh secara langsung dan tidak langsung terhadap Perilaku Pencegahan LKD. Hasil uji koefisien parameter antara dukungan nakes terhadap Perilaku Pencegahan LKD menunjukkan terdapat pengaruh langsung sebesar $22.86 \%$, sedangkan untuk pengaruh tidak langsung antara dukungan nakes terhadap Perilaku
Pencegahan LKD sebesar 0.94\%. Pengetahuan berpengaruh secara langsung dan tidak langsung terhadap Perilaku Pencegahan LKD. Hasil uji koefisien parameter antara pengetahuan terhadap Perilaku Pencegahan LKD menunjukan terdapat pengaruh langsung sebesar $20.53 \%$, sedangkan untuk pengaruh tidak langsung antara motivasi diri terhadap Perilaku Pencegahan LKD sebesar $0.24 \%$.

Hasil uji koefisien parameter antara motivasi terhadap Perilaku Pencegahan LKD menunjukan terdapat pengaruh langsung terhadap Perilaku Pencegahan LKD sebesar $22.99 \%$, sedangkan untuk pengaruh tidak langsung antara motivasi terhadap Perilaku Pencegahan LKD sebesar $0.001 \%$.

Hasil uji koefisien parameter antara sikap terhadap Perilaku Pencegahan LKD menunjukan terdapat pengaruh langsung terhadap Perilaku Pencegahan LKD sebesar $13.34 \%$, sedangkan untuk pengaruh tidak langsung antara sikap terhadap Perilaku

Pencegahan LKD sebesar $0.00 \%$. Sehingga dari masing-masing pengaruh langsung variabel laten eksogen tersebut apabila secara bersama-sama menunjukan kesesuaian dengan $\mathrm{R}$ square atau dengan kata lain hal ini menyatakan bahwa variabel dukungan nakes, pengetahuan, motivasi, dan sikap terhadap Perilaku Pencegahan LKD sebesar $(22.86 \%+$ $20.53 \%+22.99 \%+13.34 \%)=\mathbf{7 9 . 7 \%}$ 
Secara matematis, bentuk persamaan structural dari model penelitian ini adalah sebagai berikut :

$$
\eta 1=\xi \gamma_{1+} \int 1
$$

Dukungan nakes $=56.8$ pengetahuan +43.2

$$
\text { faktor lain }
$$

Dukungan nakes dipengaruhi oleh faktor pengetahuan sebesar $56.8 \%$, sisanya $43.2 \%$ dipengaruhi oleh faktor lain yang tidak diteliti dalam penelitian ini.

$$
\eta 2=\xi 1 \gamma_{1+} \xi 2 \gamma_{4+} \int 2
$$

Motivasi $=23.1$ pengetahuan +45.9 Dukungan nakes +31.0 faktor lain

Motivasi dipengaruhi oleh faktor pengetahuan sebesar $23.1 \%$, faktor dukungan nakes sebesar $45.9 \%$, faktor sikap sebesar $13.3 \%$ dan sisanya $31.0 \%$ dipengaruhi oleh faktor lain yang tidak diteliti dalam penelitian ini

$$
\eta 3=\beta_{1} \mathrm{D}_{1+} \gamma_{2} \xi 1+\gamma_{5} \xi 2+\sqrt{3}
$$

Sikap $=26.5$ pengetahuan +19.4 Dukungan

nakes + 13.8 Motivasi + 38.9 faktor lain

Sikap dipengaruhi oleh faktor pengetahuan sebesar $26.5 \%$, faktor dukungan nakes sebesar $19.4 \%$, faktor motivasi sebesar $38.9 \%$, faktor sikap sebesar $13.3 \%$ dan sisanya $0.2 \%$ dipengaruhi oleh faktor lain yang tidak diteliti dalam penelitian ini

$$
\eta 4=\beta_{2} \mathrm{D}_{2+} \gamma_{3} \xi 1+\gamma_{6} \xi 2+\int_{4}
$$

Perilaku Pencegahan LKD $=22.99$

pengetahuan +22.86 Dukungan nakes +20.63

Motivasi + 13.34 Sikap +0.203 faktor lain

Perilaku Pencegahan LKD dipengaruhi oleh faktor pengetahuan sebesar 22.99\%, faktor dukungan nakes sebesar $22.8 \%$, faktor motivasi sebesar $20.363 \%$, faktor sikap sebesar $13.3 \%$ dan sisanya $0.2 \%$ dipengaruhi oleh faktor lain yang tidak diteliti dalam penelitian ini.

\section{Pembahasan}

Kemungkinan adanya faktor subyektif responden yang sulit untuk dihindari, sehingga memungkinkan pengukuran tidak seakurat yang diharapkan. Pernyataan kurang sensitif sehingga kurang dapat menggambarkan variabel yang diteliti.Pengumpulan data dengan menggunakan kuesioner bersifat subyektif, sehingga kebenaran data sangat tergantung kepada kejujuran responden pada saat menjawab. Pengambilan sampel menggunakan purposive sampling, yaitu pengambilan data tergantung pada responden (pasien) dengan memenuhi kriteria penelitian yaitu pasien yang bersedia menjadi responden dalam penelitian ini. Keterbatasan sumber pustaka dan waktu yang singkat menyebabkan penelitian ini tidak banyak membandingkan dengan teori-teori atau pendapat yang telah ada dengan hasil penelitian.

\section{Pengaruh Pengetahuan Terhadap Perilaku Pencegahan LKD Pada Pasien Diabetes di RSUD Ungaran Semarang}

Berdasarkan hasil penelitian, dapat dilihat bahwa variabel pengetahuan dalam memberikan dorongan kepada pasien tidak dipengaruhi oleh karakteristik responden, dalam hal ini meliputi umur, pendidikan, dan pekerjaan, tidak dipengaruhi oleh karakteristik responden karena hasil uji Chi Square dengan tingkat signifikansi 5\% menunjukkan $\mathrm{P}$ value (Asymp.Sig) $>0,05$ yang menunjukkan pengetahuan tidak dipengaruhi oleh karakteristik responden.

Variabel pengetahuan tidak memiliki indikator, karena variabel ini sudah merupakan bagian dari variabel yang diukur.Pengetahuan merupakan hasil dari tahu dan ini terjadi setelah seseorang melakukan pengindraan terhadap suatu objek tertentu. Bagi responden pasien, pengetahuan sangat penting untuk dilihat, didengar dan dirasakan apa yang menjadi bagian dari penyakitnya. Jika pengetahuan pasien dikaitkan dengan perilaku hidup sehat ada indikasi pengaruh yang kuat, yaitu semakin tinggi pengetahuan pasien tentang perilaku hidup sehat, maka semakin patuh pasien menjaga hidup sehat.Kepatuhan atau ketaatan dipengaruhi oleh pengetahuan dan disiplin yang kuat dalam menjalankan prosedur yang telah ditetapkan.Pengetahuan sangat erat hubungan yang positif dengan perilaku kesehatan.Menurut Green perilaku kesehatan pada dasarnya adalah suatu respons seseorang (organisme) terhadap stimulus yang berkaitan dengan sakit dan penyakit, sistem pelayanan kesehatan, makanan serta lingkungan. ${ }^{11}$ 
Hasil penelitian ini juga diperkuat oleh penelitian terdahulu bahwa ada pengaruh pengetahuan dengan perilaku melakukan diet hipertensi pada pasien yang mengalami hipertensi. Hasil penelitian menunjukkan bahwa pasien yang berpengetahuan baik dan patuh terhadap diet hipertensi sebanyak 19 pasien $(54,30 \%)$, pasien yang berpengetahuan baik dan tidak patuh terhadap diet hipertensi sebanyak 11 pasien $(31,40 \%)$, pasien yang berpengetahuan cukup dan patuh terhadap diet hipertensi yaitu $0(0,00 \%)$, dan pasien yang berpengetahuan cukup dan tidak patuh terhadap diet hipertensi sebanyak 5 pasien $(14,30 \%){ }^{12}$

Menurut peneliti, jika kedua teori Green dan Fishbein dikaitkan akan tampak ada hubungan yang signifikan terhadap perilaku hidup sehat pada Pasien, yaitu pengetahuan seseorang akan membentuk perilaku kesehatan dan akhirnya mengarah pada hidup sehat. Sebagian besar penyakit pasien dapat dicegah dengan perilaku hidup sehat dan strategistrategi yang sudah ada dan relatif murah dan cepat melalui peningkatan pengetahuan pasien dengan cara mentaati dengan cara melakukan perilaku hidup sehat

\section{Pengaruh Dukungan Nakes Terhadap Perilaku Pencegahan LKD Pada Pasien Diabetes di RSUD Ungaran Semarang}

Dari hasil penelitian, dapat dilihat bahwa variabel dukungan nakes dalam memberikan dorongan kepada pasien tidak dipengaruhi oleh karakteristik responden, dalam hal ini meliputi umur, pendidikan, dan pekerjaan, tidak dipengaruhi oleh karakteristik responden karena hasil uji Chi Square dengan tingkat signifikansi 5\% menunjukkan $\mathrm{P}$ value (Asymp.Sig) $>0,05$ yang menunjukkan dukungan nakes tidak dipengaruhi oleh karakteristik responden.

Hasil penelitian menunjukan bahwa responden merespon dengan baik pada variabel dukungan nakes dengan ditandai nilai cross loading antar indikator terhadap variabel nya mengalami signifikan. Sedangkan pengaruh antara dukungan nakes dengan Perilaku Pencegahan LKD pada Pasien juga menunjukan angka yang signifikan, yaitu dengan menggunakan taraf kepercayaan $95 \%$ pada konstanta 1,96 dibandingkan dengan nilai didapat yaitu sebesar 4.563 jelas jauh lebih tinggi dari angka tabel nya, sehingga angka tersebut tidak bisa dianggap kecil, hal tersebut menunjukan pengaruh yang cukup tinggi, dengan nilai rho sebesar $22.86 \%$. Secara statistik telah membuktikan adanya pengaruh antara dukungan nakes diri terhadap Perilaku Pencegahan LKD pada Pasien Diabetes. ${ }^{13}$

Hasil penelitian diperkuat oleh teori bahwa bentuk peran tenaga kesehatan merupakan penyediaan materi yang dapat memberikan pertolongan langsung seperti pemberian uang, pemberian barang, makanan serta pelayanan. Bentuk ini dapat mengurangi stres karena individu dapat langsung memecahkan masalahnya yang berhubungan dengan materi.Dukungan instrumental sangat diperlukan terutama dalam mengatasi masalah yang dianggap dapat dikontrol. ${ }^{8}$

Hal yang sama juga dibuktikan oleh penelitian sebelumnya bahwa faktor-faktor yang mempengaruhi kepatuhan yang paling dominan adalah adanya dukungan tenaga kesehatan dan dukungan keluarga. ${ }^{14}$ Begitu juga hasil penelitian ini diperkuat oleh penelitian lainnya, bahwa dukungan tenaga kesehatan mempunyai hubungan kuat dan positif dengan perilaku penderita, sehingga akan membentuk perilaku yang patuh diit secara rutin untuk menghindari kejadian Luka Kaki Diabetik pada pasien diabetes. ${ }^{15}$

Menurut opini peneliti dukungan tenaga kesehatan merupakan bantuan atau dukungan yang diterima pasien diabetes dari petugas kesehatan dalam mendorong kepatuhan pasien diabetes melakukan diit. Diharapkan dengan adanya dukungan dari petugas kesehatan maka pasien diabetes akan merasa diperhatikan, dihargai dan dicintai. Dengan pemberian dukungan yang bermakna maka Ibu akan mengatasi rasa cemasnya terhadap persoalan yang dihadapinya.Dukungan dari petugas kesehatan dapat mengubah hubungan antara respon pasien diabetes sehingga dapat mengurangi stress dengan demikian akan berpengaruh baik terhadap perubahan perilaku pencegahan Luka Kaki Diabetik pada pasien diabetes.

Pengaruh Motivasi Terhadap Perilaku Pencegahan LKD Pada Pasien Di RSUD Ungaran Semarang 
HaDari hasil penelitian, dapat dilihat bahwa variabel motivasi dalam memberikan dorongan kepada pasien tidak dipengaruhi oleh karakteristik responden, dalam hal ini meliputi umur, pendidikan, dan pekerjaan, tidak dipengaruhi oleh karakteristik responden karena hasil uji Chi Square dengan tingkat signifikansi $5 \%$ menunjukkan $\mathrm{P}$ value (Asymp.Sig) $>0,05$ yang menunjukkan dukungan tenaga kesehatan tidak dipengaruhi oleh karakteristik responden.

Dorongan diaktifkan oleh adanya kebutuhan (need), dalam arti kebutuhan membangkitkan dorongan, dan dorongan ini pada akhirnya mengaktifkan atau memunculkan mekanisme perilaku. Motivasi diri mempengaruhi perilaku pasien diabetes, motivasi sebagai dorongan kebutuhan dari pasien diabetes sedangkan perilaku merupakan determinan dari motivasi tersebut, maka dapat dijelaskan sebagai berikut (1) Motivasi diri pasien diabetes merupakan dorongan potensial yang dapat menggerakkan pasien diabetes dapat berdiri dengan baik keadaan psikologis tertentu dalam diri seseorang yang muncul oleh karena adanya dorongan untuk memenuhi kebutuhan. (2) Perilaku pasien diabetes adalah hasil tindakan yang didapatkan dengan adanya stimulus motivasi diri pasien diabetes tersebut. Sehingga perilaku pasien diabetes dalam memberikan alternatif cara hidup sehat akan baik bila pasien diabetes memiliki motivasi atau kekuatan yang baik. ${ }^{16}$

Hasil penelitian ini juga sejalan dengan penelitian sebelumnya bahwa ada hubungan yang positif motivasi pasien diabetes melitus tipe 2 tentang risiko terjadinya ulkus diabetik dengan kejadian ulkus diabetik di Rsud Dr. Moewardi. Peran motivasi pasien secara tidak langsung berasal dari dukungan tenaga kesehatan untuk berperilaku mencegah kejadian ulkus diabetik. ${ }^{17}$

Menurut asumsi peneliti, bahwa motivasi pasien secara tidak langsung dapat berpengaruh terhadap hubungan dukungan tenaga kesehatan dengan perilaku pasien diabetes dalam perawatan kaki.Perawatan kaki pada pasien Diabetes Melitus penting dilakukan sendiri oleh pasien di rumah dengan waktu yang rutin.Langkah penting yang harus ditempuh sehingga pasien terdorong melakukan perawatan kaki dengan baik yaitu dengan memberikan edukasi, melalui sebuah program edukasi perawatan kaki.

\section{Pengaruh Sikap Terhadap Perilaku Pencegahan LKD Pada Pasien di RSUD Ungaran Semarang}

Dari hasil penelitian, dapat dilihat bahwa variabel sikap dalam memberikan dorongan kepada pasien tidak dipengaruhi oleh karakteristik responden, dalam hal ini meliputi umur, pendidikan, dan pekerjaan, tidak dipengaruhi oleh karakteristik responden karena hasil uji Chi Square dengan tingkat signifikansi 5\% menunjukkan $\mathrm{P}$ value (Asymp.Sig) >0,05 yang menunjukkan peran sikap tidak dipengaruhi oleh karakteristik responden.

Hasil penelitian ini juga diperkuat oleh teori bahwa sikap adalah kecenderungan yang dipelajari untuk berperilaku dengan cara yang terus menerus menyenangkan atau tidak menyenangkan terhadap suatu obyek tertentu. Mekanisme mental yang mengevaluasi, membentuk pandangan, mewarnai perasaan dan akan ikut menentukan kecenderungan perilaku individu terhadap manusia lainnya atau sesuatu yang sedang dihadapi oleh individu, bahkan terhadap diri individu itu sendiri disebut fenomena sikap. ${ }^{18}$ Fenomena sikap yang timbul tidak saja ditentukan oleh keadaan objek yang sedang dihadapi tetapi juga dengan kaitannya dengan pengalamanpengalaman masa lalu, oleh situasi di saat sekarang, dan oleh harapan-harapan untuk masa yang akan datang. Sikap manusia, atau untuk singkatnya disebut sikap, telah didefinisikan dalam berbagai versi oleh para ahli. ${ }^{19}$

Hasil penelitian ini sejalan dengan penelitian sebelumnya bahwa sebagian besar dari responden memiliki sikap yang unfavorable yaitu 21 orangatau $65,6 \%$ dan sebagian kecil dari responden memiliki sikap yang favorable yaitu 11 orang atau 34,4\% terhadap pencegahan penyakit diabetes. Hasil penelitian menunjukkan adanya hubungan antara sikap dengan sikap ibu melakukan pencegahan penyakit diabetes dengan nilai $=$ 0,045 untuk variabel sikap dan nilai $p=0,027$ untuk variabel sikap. ${ }^{20}$ 


\begin{abstract}
Menurut peneliti sikap merupakan pernyataan-pernyataan evaluatif -baik diinginkan atau tidak diinginkan mengenai objek, orang, atau peristiwa. Sikap berperan penting dalam membentuk perilaku pencegahan diabetes karena mempengaruhi perilaku orang dalam melakukan pemantauan tumbuh kembang atau tidak. Sikap yang berkaitan dengan pencegahan penyakit diabetes membuka jalan bagi secara positif atau negatif dilakukan terhadap penderita. Hal ini dapat dijelaskan bahwa sikap merupakan suatu tindakan atau aktivitas, akan tetapi merupakan predisposisi tindakan suatu perilaku. Sikap masih merupakan reaksi tertutup, bukan merupakan reaksi terbuka atau tingkah laku yang terbuka. Sikap Merupakan kesiapan untuk bereaksi terhadap objek di lingkungan tertentu, sebagai penghayatan terhadap objek. Dengan adanya hubungan antara sikap dengan sikap pasien pencegahan penyakit diabetes maka pasien seharusnya menumbuhkan sikap yang mendukung terhadap pencegahan penyakit diabetes guna mewujudkan perannya sebagai role model di masyarakat.
\end{abstract}

\section{Kesimpulan}

Perilaku Pencegahan LKD di RSUD Kelas Cianjur dipengaruhi oleh dukungan nakes, pengetahuan, motivasi kerja dan sikap. Motivasi pasien dan dukungan nakes merupakan faktor yang dominan yang sangat mempengaruhi Perilaku Pencegahan LKD di RSUD Ungaran Semarang.

\section{Saran}

Saran dalam penelitian ini adalah sebagai berikut:(1) Hendaknya bagi pihak rumah sakit lebih meningkatkan pemberian informasi yang mendalam kepada pasien dan keluarga tentang pencegahan diabetes sebagai salah satu keberhasilan terapi diabetes mellitus misalnya dengan pemberian leaflet tentang diabetes mellitus dan komplikasinya serta penyuluhan pentingnya memahami penyakit DM dengan luka kaki diabetes.(2) Bagi para pasien hendaknya lebih aktif dalam menggali dan mencari informasi khususnya tentang diabetes mellitus kaitannya dengan sikap dan kesehatan dengan cara membaca, melihat, mendengarkan dari media elektronik ataupun rajin mengikuti penyuluhan tentang diabetes mellitus.

(3) Metode penelitian ini juga hendaknya ditindaklanjuti dengan menggunakan kualitatif eksploratory, melalui observasi langsung ketika mengambil data, sehingga dapat meminimalkan bias penilaian baik oleh rater maupun responden, selain itu model ini perlu ditindaklanjuti dengan pengembangan variabel-variabel lainnya yang secara teori dapat mempengaruhi perilaku pencegahan diabetes mellitus.

\section{Daftar Pustaka}

1. Depkes RI..Buku Pedoman Pengobatan Diabetes Melitus. Jakarta: Depkes RI; 2008.

2. Dinkes Kota Bekasi.. Profil Kesehatan Kota Bekasi tThun 2009. Jawa Barat: Dinas Kesehatan; 2010.

3. Friedman, Marilyn M.. Keperawatan Keluarga Teori dan Praktek. Jakarta: EGC; 2010

4. Gibson, dkk. Organisasi : Perilaku, Struktur, Proses, Edisi Kelima, Jilid 1, Alih Bahasa Djarkasih, Jakarta; Erlangga; 2003.

5. Notoatmodjo, Soekidjo. Pendidikan dan Perilaku Kesehatan. Jakarta: Rineka Cipta;2010.

6. Subeksi,. Metabolik

Endokrin: NeuropatiDiabetik. (edisi.

V). Buku Ajar Ilmu Peyakit

Dalam). Jakarta: Interna Publising; 2010.

7. Tambunan, M. \& Gultom, Y., Perawatan Kaki Diabetes, Jakarta: Interna Publising; 2010.

8. Purnawan. Modul Pelatihan Program Lansia untuk kepatuhan Diet Diabetes Melitus. Jakarta: Rineka Cipta; 2010

9. Arikunto, Suharsimi. Prosedur Penelitian Suatu Pendekatan Praktek. Jakarta: Rineka Cipta; 2009.

10. Ghojali, I. Structural Equation Modeling Teori Konsep dan Aplikasi dengan program LISLREL 8.80, Edisi 2. Semarang: Badan Penerbit Universitas Dipenogoro; 2008.

11. Waspadji,MetabolikEndokri: Komplikasi Kronik Diabetes. Buku Ajar Ilmu Peyakit Dalam.Jakarta: Interna Publising ; 2010 
12. Masduki. Gambaran Karateristik Diabetes Melitus,Perilaku Penderita dan Pelayanan Petugas di Kabupaten Kuningan. Jawa Barat. Skripsi: 2010

13. Marrylynn, F..M and Alice, C.G.,. Rencana Asuhan Keperawatan : Pedoman Untuk Perencanaan Dan Pendokumentasian Perawatan Pasien. Jakarta, Penerbit Buku Kedokteran EGC;2008

14. Kariadi, Sri Hartini KS. Diabetes? Siapa Takut!!: Panduan Lengkap Untuk Diabetisi, Keluarganya, Dan Profesional Medis. Bandung:PT Mizan Pustaka; 2009.

15. Hasan, H, Adam, FMF, Sanusi, H, Adam, JMF. Clinical and laboratory aspect of diabetic foot infection. The Indonesian Journal of Medical Science; 2009.

16. Guyton dan Hall. Insulin,Glukagon,dan Diabetes Mellitus. Dalam Buku Ajar Fisiologi Kedokteran. (Edisi 9) Jakarta : EGC; 1997.

17. Brunner\&Suddarth. Keperawatan Medikal - Bedah. Jakarta: EGC; 2007.

18. Arisman. Obesitas Diabetes Mellitus \& Dislipidemia. Jakarta: Penerbit Buku Kedokteran EGC; 2011.

19. Askandar T. Hidup Sehat dan Bahagia bersama Diabetes Melitus. PT Gramedia Pustaka; 2006

20. Soekanto Asuhan Keperawatan Keluarga. Jakarta: EGC; 2007 